\title{
Teachers' Motivating Methods to Support Thai Ninth Grade Students' Levels of Motivation and Learning in Mathematics Classrooms
}

\author{
Sansanee Nenthien ${ }^{1} \&$ Jyrki Loima ${ }^{1,2}$ \\ ${ }^{1}$ Faculty of Education, Chulalongkorn University, Bangkok, Thailand \\ ${ }^{2}$ Faculty of Social Sciences and Business Studies, University of Eastern Finland, Finland \\ Correspondence: Sansanee Nenthien, Chulalongkorn University, 254 Pathumwan, Bangkok, 10330, Thailand. \\ Tel: 66-81-647-9215. E-mail: sansanee.n@chula.ac.th
}

\author{
Received: February 5, 2016 \\ Accepted: March 3, 2016 \\ Online Published: April 4, 2016 \\ doi:10.5539/jel.v5n2p250 \\ URL: http://dx.doi.org/10.5539/jel.v5n2p250
}

\begin{abstract}
The aims of this qualitative research were to investigate the level of motivation and learning of ninth grade students in mathematics classrooms in Thailand and to reveal how the teachers supported students' levels of motivation and learning. The participants were 333 students and 12 teachers in 12 mathematics classrooms from four regions of Thailand. The results showed, first, that the students' levels of learning ranged from low to moderate-high while the levels of motivation were from moderate to high. In addition, most students had intrinsic motivation; however, some students still lacked motivation and were only motivated by external sources. Second, teachers enhanced students' learning by encouraging them to learn as a whole class the most by using lectures and asking questions. The other top methods were allowing time for self-paced learning and answering, and relying on internal sources of motivation using positive interpersonal and group activities. Most teachers employed both autonomy-supportive and controlling motivating styles in classroom. Even with a variety of motivating methods, the students' learning did not seem to be supported adequately, especially for students who showed a low level of learning.
\end{abstract}

Keywords: mathematics classrooms, mathematics learning, motivation, motivating method, self-determination theory

\section{Introduction}

This article reports a study on the actual situation in Thailand of mathematics motivation and student learning and second, mathematics teachers' teaching methods that have either positive or negative effects on students' motivation. Mathematics is one of the core subjects in Thailand's basic education. The aims of the Basic Education Core Curriculum state that all basic education students are to achieve mathematical knowledge and skills that can be applied to real-life situations and develop positive attitude towards mathematics (Ministry of Education, Thailand, 2008). One of outstanding factors on students' positive attitude towards mathematics is their motivation to learn the subject (Teoh, Koo, \& Singh, 2010). Moreover, teacher's actions and attitudes have been found to influence students' mathematics motivation. Thus teachers, who provide intrinsic motivational sources, can have a direct effect on student learning (Loima \& Vibulphol, 2016; Middleton \& Spanias, 1999). These findings suggest that mathematics teachers should design meaningful learning activities by providing interesting tasks (Murayama, Pekrun, Lichtenfeld, \& vom Hofe, 2013; Wæge, 2009), giving real-life mathematics problems to solve (Hardré, 2011; Matteson, Swarthout, \& Zientek, 2011), and providing encouragement for successes (Githua \& Mwangi, 2003; Middleton \& Spanias, 1999), to enhance students' motivation and learning. Therefore, this study seeks to answer two Research Questions (RQs):

1) What are ninth grade students' levels of motivation and learning in mathematics?

2) How are ninth grade students' levels of motivation and learning in mathematics supported by their teachers?

By and large, this paper applied the Self-Determination Theory (SDT) developed by Deci and Ryan (Deci \& Ryan, 1995; Ryan \& Deci, 2000) and Niemiec (Niemiec \& Ryan, 2009). SDT separates motivation into two types: intrinsic and extrinsic. Intrinsic motivation involves learning behaviors that are driven by one's own internal interests, joy, or excitement and extrinsic motivation comprises learning behaviors that are performed with anticipation of outcomes apart from the activity itself (Ryan \& Deci, 2000; Reeve, 2009). Niemiec and Ryan (2009) 
offered another classification scheme for motivation, autonomous motivation and controlled motivation, based on their effects on the learning outcomes (see also Deci \& Ryan, 2008). They explained that autonomous motivation includes intrinsic motivation and some types of extrinsic motivation, the external regulations that one has identified with other aspects of self, and the actions performed because of its values. On the contrary, controlled motivation consists of the other types of extrinsic motivation - the actions performed due to external regulation such as reward or punishment, and the actions performed partly from internal pressure related to ego involvement such as to avoid shame or the feel worthy of one's self. Amotivation is defined as a lack of motivation and determination (Deci \& Ryan, 2008). Furthermore, Reeve (2009) explained two definitions of teachers' motivating style-autonomy support and controlling. The autonomy-supportive motivating style includes teachers' instructional behaviors that supports students' internal motivational resources, whereas controlling style consists of teachers' instructional behaviors that direct students to think, feel and behave in a specific way (Reeve, 2009; Reeve \& Halusic, 2009).

\section{Previous Research}

\subsection{Motivation and Learning in Mathematics}

Studies in mathematics have discussed mathematics motivation in several aspects with a common acknowledgement of motivation as an influential factor in the learning process (Gasco, Goñi, \& Villarroel, 2014; Kim, Schallert, \& Kim, 2010; Plenty \& Heubeck, 2013; Wæge, 2009). Many researchers studied the relationship between motivation and achievement. These results have shown that students' motivation was positively related to mathematics achievement (Chiu \& Xihua, 2008; Yunus \& Ali, 2009). Murayama, Pekrun, Lichtenfeld and vom Hofe (2013) investigated the relationship between student motivation and both initial level and growth of mathematics achievement from Grades 7-10 in Germany. The results showed that intrinsic motivation strongly influenced both initial level and growth of mathematics achievement, and extrinsic motivation influenced only the initial level of achievement. In addition, Zhu and Leung (2011) showed that extrinsic and intrinsic motivation directly affected mathematics achievement in East Asian students from Hong Kong SAR, Japan, the Republic of Korea, and Chinese Taipei, but not Singapore. Furthermore, intrinsic motivation strongly influenced mathematics achievement, and the influence of intrinsic motivation on students' achievement was higher than that of extrinsic motivation.

\subsection{Teacher and Students' Motivation in Mathematics Classrooms}

Gilbert et al. (2014) studied the relationship between middle school students' perceptions about classroom environment, which consisted of teacher's expectation, support, and use of reform instructional practices as well as their motivation. The results showed firstly that teacher's expectation and use of reform practices directly influenced motivation. Secondly, teacher's support directly influenced utility and mastering learning goals, while it inversely influenced performance approach and performance avoidance. At the same time, it did not significantly relate to efficiency. Matteson, Swarthout and Zientek (2011) investigated, whether teachers believed in the significance of student motivation and teachers' motivating methods in the classroom using a questionnaire. Firstly, teachers believed in the significance of student motivation. However, new teachers could not identify specific teaching methods as motivation tools, and some teachers used verbal and tangible rewards (extrinsic motivation) to motivate students. In addition, teacher preparation and professional development were required to focus on a teacher's role in constructing students' motivational beliefs and setting student learning goals. Furthermore, Maulana, Opdenakker, den Bork and Bosker (2011) found that teacher-student interpersonal behaviors, influence and proximity were significant factors of existing students' intrinsic motivation in Indonesia, and influence was more associated with extrinsic motivation. In addition, student motivation was more significantly influenced by teachers' influence. Most studies in Thailand have only tried to test instructional approaches to motivate students, except Loima and Vibulphol (2014) who qualitatively studied ninth grade students' motivation in mathematics classrooms and English classrooms of three different types of schools in Bangkok: public, private and university demonstration schools. The results showed that students' motivation was at least moderate level, and the level of students' motivation and teachers' autonomy support in mathematics classrooms were higher than those in English classrooms. However, students were still motivated by controlling and less space-giving for individual learning. Recently they published a study of countrywide learning and motivation in Thai basic education schools, paying attention to the effects of the school size. The trend indicated that smaller schools commonly had better motivated students (Loima \& Vibulphol, 2016). 


\section{Data Collection and Method Description}

This study employed a qualitative method. The population was ninth grade students in Thailand. The data were collected from twelve mathematics classrooms in four regions of Thailand: North, Northeast, Central and South. The participants were selected by stratified random sampling method. One province and its three schools of different sizes were selected randomly to represent each region, as was done in another countrywide motivation study (Loima \& Vibulphol, 2016). One mathematics classroom in each school was selected randomly by the school administrators. Mathematics teachers and students in these selected classrooms were the participants of this study. In sum, twelve mathematics teachers and 333 students participated in this study.

Each mathematics classroom was observed. After the lesson, the teacher and the students in the class answered two different questionnaires about the lesson. The two questionnaires were adapted from Loima and Vibulphol (2014, 2016). In the students' questionnaire, they were asked to describe their learning, ranging from "I did not learn most topics" to "I did learn all the topics of the lesson." There were also exemplary items for motivation, for example, "Instead of learning, I did something else during the lesson."; "The topic was not so interesting but I felt it was important to learn." and "I was strongly interested in the topics and had good motivation." These items were converted respectively into four levels of learning and motivation - none, low, moderate, and high. In addition, the students were asked to assess their ways of and interest in learning the lesson, for example, "I do not like learning but I like this subject.", which categorized into types of motivation: intrinsic motivation, extrinsic motivation, and amotivation.

In addition to students, twelve mathematics teachers were asked to assess their classrooms' situations regarding students' level of motivation and learning as well as their own motivation methods at the end of the lesson. Two researchers observed each lesson as non-participant observers. They sat at the back of the classroom and took notes of what happened during the lesson in a nonintrusive manner. The teacher and the observers were asked to analyze the students' level of motivation and learning. They were also to assess, how their methods supported their students' motivation. The teachers' motivating methods were analyzed in terms of autonomy-supportive or controlling styles (Reeve, 2009; Reeve \& Halusic, 2009) through phrases such as, "Supporting an individual student's motivation development and capacity for autonomous learning" and "Demanding students to behave in a certain way".

The levels of motivation and learning in each classroom were summarized by the triangulation of three sources: students' answers, and the comments of teacher and the two observers. If the trend of the data within and between sources was consistent, the level of learning and motivation of the classroom was identified on one of the following levels: None, Low, Moderate, or High. If the data trend did not fall into any particular level but fell between two levels, the levels of motivation and learning were clarified by assigning a midpoint of the two levels, for example, none-low, low-moderate, or moderate-high. The data from the three sources were read by two raters and when their analyses showed inconsistency, the two raters would reconsider the data and additional data until they could agree on one level. For teachers' motivating methods represented in each classroom, these were determined by the selected methods of the teacher that conformed to the observed classroom activities.

\section{Findings and Discussions}

\subsection{Students' Levels of Learning and Motivation in Thai Mathematics Classrooms}

The main finding was that the levels of motivation of ninth grade students in Thailand reached from moderate to high (see Appendix). Main finding indicated that most students were interested in mathematics topics and felt they were important to learn. This trend showed that most students had intrinsic motivation (Deci \& Ryan, 2008; Niemiec \& Ryan, 2009). This result was different from previous studies conducted among junior college and middle school students (Yee, 2010; Plenty \& Heubeck, 2013). However, the varying levels indicated that students identified different perception of topics and their value (Tsai, Kunter, Lüdtke, Trautwein, \& Ryan, 2008) and teachers' motivating styles did not clearly employ autonomy support (Reeve, 2009; Tsai et al., 2008). Teachers should explain the usefulness of topics for students' learning and future lives (Hardré, 2011), and design learning activities to enhance students' interest and engagement in learning (Jang, Reeve, \& Deci, 2010; Tsai et al., 2008). Thirdly, Thai students had various levels of mathematics learning which were classified in all scales, from low to moderate-high (see Appendix). In SDT explained that some students have inadequate autonomous motivation to enhance their learning (Deci \& Ryan, 2008; Niemiec \& Ryan, 2009). In the light of the trend, teachers should support psychological needs in the classroom also in Thailand such as using an autonomy-supportive teaching style, expanding students' ability through challenging tasks, accepting students' idea, encouraging background knowledge and skills (Niemiec \& Ryan, 2009; Tsai et al., 2008). In addition, the levels of motivation in twelve mathematics classrooms were higher than or equal to the levels of learning. This trend similarly indicated an 
existing intrinsic motivation that was not fully utilized, but no explicit trend could be shown in terms of enhanced intrinsic motivation and better performance (Chiu \& Xihua, 2008; Niemiec \& Ryan, 2009; Yee, 2010; Zhu \& Leung, 2011).

Another data finding showed that most students liked to learn mathematics and paid close attention to the lesson. In this trend, Thai students seemed to have high or, at least, moderate intrinsic motivation, while in other countries, the motivation was obviously extrinsic and performance-oriented (Kim et al., 2010; Maulana, Opdenakker, den Bork, \& Bosker, 2011; cf., Loima \& Vibulphol, 2016). Likewise, approximately 10 percent of the students responded to mathematics lessons that they did not like learning but since their teacher was good, they liked his/her teaching. This meant that teachers were directly influencing student motivation, which is similar to the results of previous studies (Matteson et al., 2011; Supha \& Pithuncharurnlap, 2013), and it was classified as extrinsic motivation because students performed their tasks based on extrinsic incentive not their own interest as Ryan and Deci stated (2000). This indicated that teachers' teaching style should employ more autonomy support in order to bring out students' intrinsic motivation in mathematics (Reeve, 2009; Reeve \& Halusic, 2009). Irrespective of this, the number of students who replied that they did not fully concentrate on learning and thought about other things during the lessons was also about 10 percent. This finding pointed out that mathematics activities and lessons did not attract these students to learn. The reason might simply have been the nature of mathematics as a subject and its required tasks, as well as students' lack of interest and ability in mathematics (Hardré, 2011; Middleton \& Spanias, 1999; Ryan \& Deci, 2000). No matter what was the accurate reason for Thai students, the data suggested that mathematics teachers should provide meaningful learning activities to enhance each individual student's motivation.

Finally, these results tend to show that some students who had no motivation to learn mathematics had a low level of learning (Chiu \& Xihua, 2008; Yunus \& Ali, 2009). Teachers should help students to have the sense of achievement in mathematics lessons and to gain awareness that everyone can be successful if they put enough effort into succeeding at their task (Middleton \& Spanias, 1999).

\subsection{How Teachers Support Students' Levels of Motivation and Learning by Motivating Methods}

In this research, teachers' motivating methods were considered as the ways that teachers enhance students' levels of motivation and learning in mathematics classrooms. The findings indicated that the teachers used "encouraging students at the group level for learning as a class" the most by giving lectures and asking questions to enhance motivation, as was found by Hardré (2008), Matteson et al. (2011), and Loima and Vibulphol (2014). These motivating methods may be characterized as controlling styles (Reeve, 2009). However, some trends from teachers' perception and the remarks of observers revealed other top methods in the present study. One was "allowing time for self-paced learning and answering". The teachers in many classes tended to provide time for the students to solve math problems. This finding was similar to a study that students in Japanese classrooms were given enough time to think and solve problems, while students in the United States were rushed through math exercises (Geist, 2000). Furthermore, Middleton and Spanias (1999) found that having suitable time to solve math problems would increase students' motivation to do the task. Another common motivating method was "relying on internal sources of motivation e.g., interest, positive learning atmosphere" such as creating group activities and positive interpersonal relationship. Group activities were one of the motivating methods employed by experienced teachers (Matteson et al., 2011). Studies have shown that mathematics motivation can be improved by using integrated group discussions and teamwork in mathematics activities (Deacon \& Edwards, 2012; Katekaew, 2004; Parikarn, 2010). When it comes to interpersonal relationships, Maulana et al. (2011) found that teachers' perception about their relationship with their students was at the moderate level, while Hardré (2011) revealed that teachers' interpersonal relationship in mathematics classrooms was less than that in elective subjects. However, positive interpersonal relationships affected students' motivation (Gilbert et al., 2014; Maulana et al., 2011). In the Thai context, this kind of attentive interpersonal approach might serve as a motivating factor.

\subsection{Actual Situations in Some Mathematics Classrooms: Teachers' Motivating Activities in Classes with Moderate and High Level of Motivation}

Even though the teachers tended to use several motivating methods to encourage students to learn during lessons but the students' level of mathematics learning and motivation in Thailand still varied - not all the classes showed high levels as expected-actual situations in categorized mathematics classrooms were presented with teachers' motivating methods (Loima \& Vibulphol, 2014; Reeve, 2009).

Only two classrooms demonstrated a moderate level of motivation. A teacher's motivating method found in one classroom with a low-moderate level of learning was controlling style, while another with a low level of learning was autonomy-supportive style (see Appendix). It was also found that teacher's performance in motivating and 
giving space to students' learning was best at the beginning of a lesson. The teacher would introduce the topic in a way that got the students interested. They then tended to patiently wait for students' answers, and then the students worked on a worksheet individually. These performances were associated with instruction behaviors of autonomy-supportive motivating style. After that, the class changed to be teacher-centered which was at the same time controlling motivating style. Some students then started to lose their interest when the teacher concentrated on the first row of class. In addition, a few students who came late did not follow the lesson as they did not get their teacher's attention and so started to disturb the other students during the lesson. According to SDT, a controlling style teacher obstructs students' motivation and learning (Jang, Kim, \& Reeve, 2012; Loima \& Vibulphol, 2016; Reeve, 2009).

There were four classrooms ranked in the high level of motivation. The teachers' instructional methods in these classrooms were both autonomy support and controlling. Three of the classes were placed in the moderate level of learning, while the other was ranked in the moderate-high level of learning. In the latter classroom, the teacher showed controlling motivating style by lecturing. The teacher lectured and clearly showed, how to solve each mathematics problem step by step, and asked questions throughout the lesson. The teacher gave an exercise and enough time for individual practice and provided tips or principles on how to do the exercise. This teacher's instructional style was based on structures that provided strongly guided instruction and learning activities (Jang et al., 2010). Indeed, the autonomy-supportive style and structure contributed to students' engagement (Jang et al., 2010). Engaging mathematics activities promoted students' motivation (Middleton \& Spanias, 1999; Stipek et al., 1998, as cited in Wæge, 2009) and students' motivational development had a positive effect on their learning (Jang et al., 2010; cf., Loima \& Vibulphol, 2016).

\section{Conclusions and Suggestions}

The present study investigated the level of motivation and learning of Thai ninth grade students. It was found that the level of learning of Thai students ranged from low to moderate-high and the level of motivation was moderate to high, while at least ten percent of the students lacked motivation. These findings show that some students did not perceive their teacher's motivating support, especially amotivation students or low level of learning students. Therefore, mathematics teachers should develop motivating methods to create autonomy support.

In this research, teachers' motivating strategies were clarified by the teachers and classroom activities, but the students did not get to reflect their perception about the teacher's motivation methods in the class. To be able to prepare teachers to encourage students' motivation in mathematics more effectively, further studies should investigate the students' perception on teacher motivational support in actual mathematics classroom situations, and to explore students' needs about motivation support in mathematics lessons. Since there was wide variety of methods in this data, teacher student's interest in developing motivating methods should also be studied.

\section{Acknowledgements}

Authors would like to thank Ratchadaphiseksomphot Endowment Fund, Chulalongkorn University for financial support. Special thanks to our research team for their assistance and collaboration.

\section{References}

Chiu, M. M., \& Xihua, Z. (2008). Family and motivation effects on mathematics achievement: Analyses of students in 41 countries. Learning and Instruction, 18(4), 321-336.

Deacon, D., \& Edwards, J. A. (2012). Influences of friendship groupings on motivation for mathematics learning in secondary classrooms. In C. Smith (Ed.), Proceedings of the British Society for Research into Learning Mathematics (Vol. 32, No. 2, pp. 22-27). Retrieved from http://www.bsrlm.org.uk/IPs/ip32-2/BSRLM-IP-32-2-04.pdf

Deci, E. L., \& Ryan, R. M. (1995). Human autonomy: The basis for true self-esteem. In M. H. Kernis (Ed.), Efficacy, agency, and self-esteem (pp. 31-49). New York, NY: Springer. http://dx.doi.org/10.1007/978-1-4899-1280-0_3

Deci, E. L., \& Ryan, R. M. (2008). Self-determination theory: A macrotheory of human motivation, development, and health. Canadian Psychology, 49(3), 182-185. http://dx.doi.org/10.1037/a0012801

Gasco, J., Goñi, A., \& Villarroel, J. D. (2014). Sex differences in mathematics motivation in 8th and 9th grade. Procedia-Social and Behavioral Sciences, 116, 1026-1031. http://dx.doi.org/10.1016/j.sbspro. 2014.01 .340

Geist, E. A. (2000). Lessons from the TIMSS videotape study. Teaching Children Mathematics, 7(3), 180-185. 
Gilbert, M. C., Musu-Gillette, L. E., Woolley, M. E., Karabenick, S. A., Strutchens, M. E., \& Martin, W. G. (2014) Student perceptions of the classroom environment: Relations to motivation and achievement in mathematics. Learning Environments Research, 17(2), 287-304. http://dx.doi.org/10.1007/s10984-013-9151-9

Githua, B. N., \& Mwangi, J. G. (2003). Students' mathematics self-concept and motivation to learn mathematics: Relationship and gender differences among Kenya's secondary-school students in Nairobi and Rift Valley provinces. International Journal of Educational Development, 23(5), 487-499. http://dx.doi.org/10.1016/S0738-0593(03)00025-7

Hardré, P. L. (2008). Taking on the motivating challenge: Rural high school teachers' perceptions and practice. Teacher Education and Practice, 21(1), 72-88.

Hardré, P. L. (2011). Motivation for math in rural schools: Student and teacher perspectives. Mathematics Education Research Journal, 23(2), 213-233. http://dx.doi.org/10.1007/s13394-011-0012-5

Jang, H., Reeve, J., \& Deci, E. L. (2010). Engaging students in learning activities: It is not autonomy support or structure but autonomy support and structure. Journal of Educational Psychology, 102(3), 588-600. http://dx.doi.org/10.1037/a0019682

Jang, H., Kim, E. J., \& Reeve, J. (2012). Longitudinal test of self-determination theory's motivation mediation model in a naturally occurring classroom context. Journal of Educational Psychology, 104(4), 1175-1188. http://dx.doi.org/10.1037/a0028089

Katekaew,

S.

(2004) ผลของการใช้กระบวนการสื่อสารที่มีต่อผลสัมฤทธิ์ทางการเรียนวิชาคณิตศาสตร์และแรงจูงใจใฝ่สสัมฤทธิ์ในกา รเรียนคณิตศาสตร์ของนักเรียนระดับมัธยมศึกษาตอนต้น [Effects of using communication process on mathematics learning achievement and achievement motivation towards mathematics of lower secondary school students] (Unpublished master's thesis). Chulalongkorn University, Thailand. Retrieved from http://cuir.car.chula.ac.th/bitstream/123456789/434/3/Sutida.pdf

Kim, J. I., Schallert, D. L., \& Kim, M. (2010). An integrative cultural view of achievement motivation: Parental and classroom predictors of children's goal orientations when learning mathematics in Korea. Journal of Educational Psychology, 102(2), 418-437. http://dx.doi.org/10.1037/a0018676

Loima, J., \& Vibulphol, J. (2014). Internal interest of external performing? A Qualitative study on motivation and learning of 9th graders in Thailand basic education. Journal of Education and Learning, 3(3), 194-203. http://dx.doi.org/10.5539/jel.v3n3p194

Loima, J., \& Vibulphol, J. (2016). Learning and motivation in Thailand: A Comparative Regional Study on Basic Education Ninth Graders. International Education Studies, 9(1), 31-43. http://dx.doi.org/10.5539 /ies.v9n1p31

Matteson, S. M., Swarthout, M. B., \& Zientek, L. R. (2011). Student motivation: Perspectives from mathematics teachers. Action in Teacher Education, 33(3), 283-297. http://dx.doi.org/10.1080/01626620.2011.592123

Maulana, R., Opdenakker, M. C., den Brok, P., \& Bosker, R. (2011). Teacher-student interpersonal relationships in Indonesia: Profiles and importance to student motivation. Asia Pacific Journal of Education, 31(1), 33-49. http://dx.doi.org/10.1080/02188791.2011.544061

Middleton, J. A., \& Spanias, P. A. (1999). Motivation for achievement in mathematics: Findings, generalizations, and criticisms of the research. Journal for Research in Mathematics Education, 30(1), 65-88. http://dx.doi.org/10.2307/749630

Ministry of Education. (2008). Basic education core curriculum B.E.2551 (A.D.2008). Retrieved from http://academic.obec.go.th/web/doc/d/147

Murayama, K., Pekrun, R., Lichtenfeld, S., \& vom Hofe, R. (2013). Predicting long-term growth in students' mathematics achievement: The unique contributions of motivation and cognitive strategies. Child Development, 84(4), 1475-1490. http://dx.doi.org/10.1111/cdev.12036

Niemiec, C. P., \& Ryan, R. M. (2009). Autonomy, competence, and relatedness in the classroom: Applying self-determination theory to educational practice. Theory and Research in Education, 7(2), 133-144. http://dx.doi.org /10.1177/1477878509104318

Parikarn,

$\mathrm{N}$.

(2010). ผลของการจัดกิจกรรมโครงงานคณิตศาสตร์ที่มีต่อทักษะการแสวงหาความรู้ด้วยตนแองและแรงจงใจใฝ่สัมฤท ธิ์ในการเรียนวิชาคณิตศาสตร์ของนักเรียนชั้นมัธยมศึกษาปีที่ 2 [The effects of using mathematics project 
approach on knowledge seeking skill and achievement motivation in mathematics of mathayomsuksa II students] (Unpublished master's thesis). Srinakarinwirot University, Thailand. Retrieved from http://thesis.swu.ac.th/swuthesis/Ed_Re_Sta /Narintorn_P.pdf

Plenty, S., \& Heubeck, B. G. (2013). A multidimensional analysis of changes in mathematics motivation and engagement during high school. Educational Psychology, 33(1), 14-30. http://dx.doi.org/10.1080/01443410.2012.740199

Reeve, J. (2009). Why teachers adopt a controlling motivating style toward students and how they can become more autonomy supportive. Educational Psychologist, $44(3), \quad 159-175$. http://dx.doi.org/10.1080/00461520903028990

Reeve, J., \& Halusic, M. (2009). How K-12 teachers can put self-determination theory principles into practice. Theory and Research in Education, 7(2), 145-154. http://dx.doi.org/10.1177/1477878509104319

Ryan, R. M., \& Deci, E. L. (2000). Intrinsic and extrinsic motivations: Classic definitions and new directions. Contemporary Educational Psychology, 25, 54-67. http://dx.doi.org/10.1006/ceps.1999.1020

Supha, L., \& $\quad$ \& $\quad$ Pithuncharurnlap, $\quad$ M. ปัจจัยที่มีผลต่อแรงจงใจใฝ่สัมฤทธิ์ทางการเรียนวิชาคณิตศาสตร์ของนักเรียนชั้นมัธยมศึกษาปีที่2 โรงเรียนรัต นโกสินทร์สมโภชลาดกระบัง [Factors affecting the mathematics learning achievement motivation of Rattanakosinsomphotlatkrabang mathayomsuksa 2 students]. Journal of Science Ladkrabang, 22(2), 38-50.

Teoh, S. H., Koo, A. C., \& Singh, P. (2010). Extracting factors for students' motivation in studying mathematics. International Journal of Mathematics Education in Science and Technology, 44(6), 711-724. http://dx.doi.org/10.1080/00207391003675190

Tsai, Y. M., Kunter, M., Lüdtke, O., Trautwein, U., \& Ryan, R. M. (2008). What makes lessons interesting? The role of situational and individual factors in three school subjects. Journal of Educational Psychology, 100(2), 460-472. http://dx.doi.org /10.1037/0022-0663.100.2.460

Wæge, K. (2009). Motivation for learning mathematics in terms of needs and goals (pp. 84-93). Proceedings of CERME 6, January $28^{\text {th }}$-February 1st 2009. Retrieved from http://www.inrp.fr/editions/cerme6

Yee, L. S. (2010). Mathematics attitudes and achievement of junior college students in singapore. In L. Sparrow, B. Kissane, \& C. Hurst (Eds.), Shaping the future of mathematics education: Proceeding of the $33^{\text {rd }}$ annual conference of the Mathematics Education Research Group of Australasia (pp. 681-689). Western Australia, Australia: MERGA. Retrieved from http://files.eric.ed.gov/fulltext/ED521019.pdf

Yunus, S. A. M., \& Ali, W. Z. W. (2009). Motivation in the learning of mathematics. European Journal of Social Sciences, $\quad 7(4), \quad 93-101 . \quad$ Retrieved from http://psasir.upm.edu.my/7008/1/European_Journal_of_Social_Sciences _ _ _Number_4_(2009)_2.pdf

Zhu, Y., \& Leung, F. K. S. (2011). Motivation and achievement: Is there an East Asian model? International Journal of Science and Mathematics Education, 9, 1189-1212.

\section{Notes}

Note 1. Kind of teacher's motivating methods

a) Demanding students to behave in certain way

b) Paying special attention and giving support to weakest students

c) Supporting individual student's motivation development and capacity for autonomous learning

d) Encouraging students at the group level for learning as a class

e) Correcting the wrong/unexpected answers immediately

f) Allowing time for students' self-paced learning and answering

g) Motivating students using external sources, e.g. score, punishment

h) Relying on internal sources of motivation, e.g. interests, positive learning atmosphere

Note 2 . The motivating method identified by the teacher was not observed. 


\section{Appendix}

The Data Finding from Twelve Classrooms in Mathematics

\begin{tabular}{|c|c|c|c|c|c|c|c|}
\hline \multirow[t]{2}{*}{ Class } & \multirow[t]{2}{*}{$\begin{array}{l}\text { No. of } \\
\text { students }\end{array}$} & \multirow[t]{2}{*}{$\begin{array}{l}\text { Level of } \\
\text { Learning }\end{array}$} & \multirow[t]{2}{*}{$\begin{array}{c}\text { Level of } \\
\text { motivation }\end{array}$} & \multicolumn{3}{|c|}{$\begin{array}{c}\text { No. of students' self-perception on } \\
\text { type of Motivation }\end{array}$} & \multirow{2}{*}{$\begin{array}{c}\text { Teacher's } \\
\text { motivating } \\
\text { method }^{1}\end{array}$} \\
\hline & & & & Intrinsic & Amotivation & Extrinsic & \\
\hline 1 & 21 & MOD & MOD-HIGH & 20 & 1 & 0 & $\mathrm{f} / \mathrm{h}$ \\
\hline 2 & 32 & MOD-HIGH & HIGH & 30 & 0 & 2 & $\mathrm{~d} / \mathrm{h}$ \\
\hline 3 & 35 & MOD-HIGH & MOD-HIGH & 30 & 3 & 2 & $\mathrm{~b} / \mathrm{c} / \mathrm{d} / \mathrm{f} / \mathrm{h}$ \\
\hline 4 & 21 & LOW-MOD & MOD-HIGH & 20 & 0 & 0 & $\begin{array}{c}\text { Inconsistent } \\
\text { among sources }^{2}\end{array}$ \\
\hline 5 & 19 & LOW-MOD & MOD-HIGH & 14 & 1 & 4 & $\mathrm{f}$ \\
\hline 6 & 31 & LOW & MOD & 15 & 10 & 6 & $\mathrm{f}$ \\
\hline 7 & 9 & MOD & HIGH & 8 & 0 & 1 & $\mathrm{~d} / \mathrm{h}$ \\
\hline 8 & 32 & LOW-MOD & MOD & 25 & 5 & 2 & $\mathrm{~d} / \mathrm{g}$ \\
\hline 9 & 47 & MOD & MOD-HIGH & 31 & 5 & 11 & $\mathrm{~d}$ \\
\hline 10 & 13 & MOD & HIGH & 13 & 0 & 0 & $\mathrm{c} / \mathrm{d} / \mathrm{g} / \mathrm{h}$ \\
\hline 11 & 28 & MOD & HIGH & 24 & 2 & 2 & $\mathrm{c} / \mathrm{d}$ \\
\hline 12 & 45 & MOD & MOD-HIGH & 30 & 9 & 6 & $\mathrm{~d} / \mathrm{f}$ \\
\hline
\end{tabular}

\section{Copyrights}

Copyright for this article is retained by the author(s), with first publication rights granted to the journal.

This is an open-access article distributed under the terms and conditions of the Creative Commons Attribution license (http://creativecommons.org/licenses/by/3.0/). 